\title{
Post-Financial Crises Puzzle of Economic Growth in Low and Lower-Middle Income Countries: Evidence from Static and Dynamic Panel Estimations
}

Mohammad m shafiq ( $\sim$ musa.shafiq@gmail.com )

Universite de Strasbourg 1: Universite de Strasbourg https://orcid.org/0000-0002-4191-3549

Bosede Ngozi ADELEYE

Covenat Uni

\section{Research}

Keywords: economic growth, financial crises, low-income countries, dynamic panel

Posted Date: September 8th, 2020

DOI: https://doi.org/10.21203/rs.3.rs-70020/v1

License: (c) (1) This work is licensed under a Creative Commons Attribution 4.0 International License.

Read Full License 


\title{
Post-Financial Crises Puzzle of Economic Growth in Low and Lower-Middle Income Countries: Evidence from Static and Dynamic Panel Estimations
}

\begin{abstract}
This paper investigates economic growth in 65 low and lower-middle-income countries from 2010 to 2017. Results from static and dynamic panel data techniques show that foreign direct investment (FDI), capital formation, and labor force significantly increase economic growth while government expenditure decreases growth. Mobile phone subscription reveals no significant impact on growth at aggregate levels. Furthermore, analyses at the income group level reveal substantial differences between the determinants of economic growth in low and lower-middle-income countries. For instance, FDI is a significant predictor of growth in low-income countries, but not in lower-middleincome countries. Similarly, government expenditure and mobile cellular subscriptions are not significant predictors in low-income countries relative to lower-middle-income countries. Interestingly, capital formation and labor force are the two common significant predictors across low and lower-income countries.
\end{abstract}

Keywords: economic growth; financial crises; low-income countries; dynamic panel

\section{Introduction}

This study interrogates the post-financial growth scenario in low and lower-middle-income countries. Growth is a puzzle, and financial instability makes it more complicated. Still, there is no clear understanding of what causes nations around the world to be poor, and what exactly stimulate the growth and poverty reduction. Millions die due to hunger, and the statistics of poor with less than a dollar income per day surges around the world (Banerjee and Duflo, 2011). On average, per capita income, which is often used as a measure of income, is significantly higher in developed economies than in developing economies.

Financial instability has contributed to the complexity of economic growth. In particular, when financial crises lead to recessions, it will likely cause persistent shortfalls in output and longterm effect (Blanchard, Cerutti and Summers, 2015; Cerra and Saxena, 2017). For instance, the great depression of 1929 , known as the worst economic disaster of the $20^{\text {th }}$ century, caused massive output losses, record unemployment, and enormous income losses. The crisis lasted ten years, and the consequences persisted for centuries. Similarly, the Asian crises of 1997 originated in Thailand, spread quickly to the East Asian countries and the trading partners. The panic in the Asian financial market led to the reversal and loss of billions of dollars of foreign investment. The 
horror and fear of a worldwide economic meltdown spread across the world. The International Monetary Fund (IMF) had to step in and create relief packages to rescue the economy. It took years for the economy to recover.

Despondently, the financial crisis of 2008-2009, also took a massive toll on the world economy. The crisis originated from the US and spread like wildfire across the Atlantic to Europe. After the burst of the housing bubble, it paralyzed the credit flow and led to the bankruptcy of numerous financial institutions. Though the crisis originated from the advanced economy, it overlaid developing countries as well. The primary channel that crises transmitted to developing countries was reduction of trade and disruption of capital flows (Aizenman et al., 2018). Simultaneously with the abruption of credit flow, the business and consumer confidence diminished, investment and economic activity plummeted, which in turn crimped the economic growth. The crisis wiped out an estimated \$2.6 trillion in output (Dolphin and Chappell, 2010). In emerging and developing countries, the real GDP growth fell to 2.4 percent in 2009, from 8.3\% in 2008 (IMF, 2010).

However, the main challenge is economic recovery after the crisis. It takes years to regain the growth pace and bounce back to the level of pre-crisis. Study indicates that, on average, it takes almost eight years for the advanced economies to reach the pre-crisis level of growth (Reinhart and Rogoff, 2014). Particular to the 2008 financial crises, among the 12 developed economies ${ }^{1}$, only the US and Germany were able to reach the pre-crisis growth level within five to six years (Reinhart and Rogoff, 2014). After the financial crisis of 2008, growth level, growth volatility, and macroeconomic fundamentals have changed. Growth across countries does not depend only on internal factors, but it also depends on external factors such as the global growth rate (Aizenman et al., 2018). Following this view, this study focus on economic growth in low and lower-middleincome countries. We evaluate the influence of common growth's determinant in the post-financial crises of 2008 on the economic growth of 65 low and low-income countries.

Our focus is mainly on the factors that literature indicates as the determinant of economic growth. We use the annual rate of gross domestic product (GDP) as a proxy for economic growth. Foreign

\footnotetext{
${ }^{1}$ For list of countries and measnurment methods refer to Reinhart and Rogoff, 2014.
} 
direct investment (FDI), gross capital formation (GCF), general government final consumption expenditure (GE), labor force participation (LF), mobile phone subscription (MOB), and inflation (INF) as the predictors of growth. We perform our analyses on the 65 low and lower-income countries. Using income level similarities, we would like to see what predictors have influenced the growth after the financial crisis. We are optimistic that our findings will stimulate useful and practical policy debates that will boost economic growth. The rest of this paper is structured as follows: Section 2 reviews the extant literature, Section 3 outlines the data and empirical model, Section 4 analyses and discusses the results, and Section 5 concludes with policy implications.

\section{Review of Extant Literature}

The effect of financial crises on economic growth was significant and persistent. Immediately after the panic in late 2008, 91 economies experienced declines in output in 2009 (Chen, Mrkaic and Nabar, 2019). From the economy stacked in the financial crisis, 85 percent still show negative deviations after a decade (Chen, Mrkaic and Nabar, 2019). Most countries experienced shortfalls in credit follow, which leads sluggish investment, reduced output (Blanchard, Cerutti and Summers, 2015; Carare et al., 2018).

Furthermore, coupled with the high population growth, the crisis caused a $20 \%$ drop in per capita income of the 390 million poor in Africa (Gurtner, 2010) added as much of 89 million individuals to the number of people living on less than $\$ 1.25$ a day. The crisis increased the dimensions of poverty and took at least 50 million jobs (Naudé, 2009; McCord, 2010; Ratha, Mohapatra and Silwal, 2010). The financial crises impacted countries around the world from different perspectives. Mainly the consequences spread to the developing countries through the decline in trade, capital flows, and remittances (Griffith-Jones and Ocampo, 2009). The crises hampered global trade, which fell by $11 \%$ in 2009 (Naudé, 2010). The decrease in industrial output in the developed countries contracted trade volume and particularly demand for raw materials from developing countries (Griffith-Jones and Ocampo, 2009; Sen, 2011). For instance, during the first half of 2009, export income in the 49 low-income countries decreased by $43.8 \%$ (Gurtner, 2010). As a result of collapsing demand for raw materials in the emerging market, the revenue stream of African metal exporting countries who were exporting raw material to India and china stagnated. The price of metals and agricultural goods fell by 50\% and 30\%, respectively (World Bank, 2010). 
Also, the crisis decreased remittances to low-income countries. Regions such as Central Asia and Eastern Europe, Latin America, and Caribbean experienced a drop of $-20.7 \%$ and $-12.3 \%$, respectively (Ratha, Mohapatra and Silwal, 2010). Countries such as Morocco and Tunisia who are heavily reliant on remittances, lost up to two percent of their GDP (Chami et al., 2010).

The financial crisis of 2008 impacted investments, particularly foreign direct investments. Due to uncertainties, investors directed their money to safe-havens, such as the US treasury. In 2008, capital flow from developing countries dropped to US\$727 million from US\$1.6 trillion in 2007 (Ratha, Mohapatra and Silwal, 2010). Literature indicates the importance of foreign direct investment (FDI) on economic growth; according to the neoclassical growth theory, FDI inflow stimulates economic growth by increasing the capital stock (De Mello, 1997; Herzer, 2012). FDI promotes export and expands the revenue stream, which, in turn, enables the funding of public investment projects (Sylwester, 2005). Furthermore, it enhances the productivity of firms in host countries by transferring technical skills and business knowledge, which improves economic growth (Romer, 1993). In other words, in addition to the change in the supply-demand relationship of monetary capital, FDI influences the division of labor and the transfer of knowledge and skills (Qiang, 2013).

However, there is skepticism about the crowding-out effect of FDI. Some studies reveal that in many developing countries, FDI is associated with externalities and weakening of the growth rate (Agosin and Machado, 2005; Kumar and Pradhan, 2005). Other studies argue that FDI may boost just the economy of countries with relatively high levels of human capital, substantial property rights, and bureaucratic efficiency (Borensztein, De Gregorio and Lee, 1998; Olofsdotter, 1998). FDI may also transfer profit to foreigners that may decrease welfare in host countries, particularly in the countries that import capital-intensive goods (Brecher and Diaz Alejandro, 1977; Balcão Reis, 2001). Therefore, despite the direction and magnitude of the effect, FDI is a critical determinant of economic growth.

In the meantime, government expenditure was also shrunk after the financial crisis of 2008 . The government expenditure is used as a fiscal policy tool to correct short-run fluctuations to facilitate long-run growth. However, its impact on growth is questionable. Commonly, Wanger's law and Keynesian hypothesis are the bases for debate on the effects of government expenditure on 
economic growth. According to Wanger (1983), government expenditures are endogenous growth factors but not as the cause of economic growth. This theory suggests causality between public expenditure and national income from national income to government expenditure. Based on Wanger's law, an increase in government expenditure is due to economic growth (IMF, 1988; Nyasha and Odhiambo, 2019).

Contrarily, Keynes(1936) considers government expenditure as an exogenous factor that accelerates growth. Keynesian school of thought encourages governments to undertake proactive fiscal policy measures and instruments to boost economic growth. The government can offset the pace of growth by increasing government spending or cutting taxes; hence, fiscal policy is used as counter-cyclical tools that alleviate short-run fluctuations in output and employment (Zagler and Dürnecker, 2003). Since then, several studies have noted positive correlations between government spending and economic growth (Aschauer, 1989; Ram, 1989; Holmes and Hutton, 1990). Likewise, increase the total output, provision of public goods and infrastructures, social services, and other interventions such as export subsidies are the main channels of influence of government expenditures on growth (Lin, 1994). Similarly, Ghosh and Gregoriou (2008) find government spending as a significant factor in the growth pattern of 15 developing countries.

However, government expenditures or the overall effectiveness of fiscal policy in stabilizing aggregate demand should check and balance various aspects. Spending on investment and productive activities positively contribute to economic growth (Barro, 1990). Likewise, government expenditure on infrastructure and projects that increase physical and human capital stock, and complements the private investment leads to growth (Landau, 1983; Barro and Sala-IMartin, 1992; Kneller, Bleaney and Gemmell, 1999). Government expenditure that does not increase revenue leads to budget deficits. Financing budget deficit through domestic debt can have negative consequences on the domestic interest rate, crowds out the private consumption and investment. Meanwhile, financing deficit by monetary policy leads to expansaiton of credit and over-liquidity causing inflation, which in turn results in higher nominal interest rates leading to contraction of private spending (Loizides and Vamvoukas, 2005; Kandil, 2006).

In addition to the two hypotheses mentioned above, the neoclassical growth model of Solow (1956) does not consider government expenditure as a determinant of economic growth. Based on this 
model, fiscal policy does not stimulate long-run growth. In the same vein, Grier and Tullock (1989) document a negative relationship between government expenditure and growth. Barro (1989), on his endogenous model, finds a negative correlation between GDP growth and government expenditure and noted that government expenditures do not stimulate investment and growth, instead distort the economy. Aligned with Barro (1990), Barro (1989) asserts that only expenditures on investment and productive activities lead to growth.

Similarly, government expenditure in low-income countries might be associated with the crowding-out effect. Due to capital scarcity, low-income countries rely on imports to carry out public investment, which does not stimulate output and growth, at least in the short run(Shen, Yang and Zanna, 2018). Therefore, the view that government expenditure can stimulate the short-run demand and long-run growth engine is different in the low-income countries (Traum and Yang, 2015; Abiad, Furceri and Topalova, 2016).

Aggregate production function considers other factors that influence economic performance. According to this model, economic growth depends on technological innovation and macroeconomic inputs. Specifically, the accumulation of physical and human capital and the discovery of new technologies enhance economic growth (Solow, 1956). The underlying assumptions of this growth model are diminishing marginal productivity and increasing returns on the scale (Pegkas and Tsamadias, 2016). Physical and human capital enhance growth (Romer, 1986, 1990; Mankiw, Romer and Weil, 1992; Sianesi and Van Reenen, 2003). Human capital empowers the process of creating and adopting new ideas. Studies have confirmed the impacts of human capital both in developed and developing countries (Loening, 2005; Bloom, Canning and Chan, 2006; Pegkas and Tsamadias, 2014).

Investments create job opportunities and enhance purchasing power by increasing the per capita income, which creates more effective demand. Similarly, capital formation leads to an increase in production. Capital formation can break the vicious circle of poverty in an economy (Nurkse, 1971). At the same vein, the literature shows positive relationships between growth and information technology (Papaioannou and Dimelis, 2007; Dedrick, Kraemer and Shih, 2013; Niebel, 2018). Technology enhances growth by increasing productivity and efficiency. Innovation in the production process decreases the marginal cost and total production cost. At the micro-level, 
technology increase the market power, and at the macro level, as Adeleye and Eboagu (2019) showed, technology enhances growth. Hence, this paper evaluates the impact of macroeconomic predictors on the economic growth of low and lower-middle-income countries. Our study uses FDI, government expenditure, and capital formation to explain economic growth while controlling for technology and microeconomic stability.

\section{Data and Model}

The study uses balanced panel data of 65 low and lower-middle-income countries. All variables are sourced from the World Bank (2019) World Development Indicators (WDI) from 2010 to 2017. Categorization of countries into low and lower-middle-income is adopted from the World Bank (2018) classification (see Appendix Table 1A for the list of countries). Given the structure of our data $(N>T)$, both static and dynamic panel techniques are adopted. The results from the static models give a general view of the overall performance of the indicators. However, to overcome the problem of endogeneity, heteroskedasticity, and omitted variable bias, the system generalized method of moments (Sys-GMM) is used to complement our findings. This is because the Sys-GMM technique captures the dynamic nature of economic growth in addition to using additional instruments, which makes the estimator more efficient when compared to the other techniques.

\section{$3.1 \quad$ Variables}

The study uses a total of seven variables. The dependent variable is the annual rate of gross domestic product (GDP), which is the proxy for economic growth. It shows the yearly percentages of change in GDP growth. The explanatory variables are foreign direct investment (FDI), gross capital formation (GCF), general government final consumption expenditure (GE), labor force

participation (LF), mobile phone subscription (MOB), and inflation (INF) which is a macroeconomic variable included for robustness checks. FDI, GCF, and GE are expressed in terms of percentages of GDP.

Two variables are used as the measure of investment - FDI, and GCF. FDI measures the values of inward direct investment by the non-resident of a country, while GCF is the total stock of domestic investment in an economy plus net changes in the level of inventories in a country. It also includes 
the total value of the gross fixed capital formation, changes in inventories, and acquisition of valuables. Both variables are included because development is investment-driven (Dunne and Masiyandima, 2017; Adeleye and Eboagu, 2019; Adom, Opoku and Yan, 2019). Total labor force and mobile cellular subscriptions are used as proxies for factors of production. The labor force is required for production which is key to growth (Jawaid and Waheed, 2017; Adeleye and Eboagu, 2019; Jacobs, Rivett and Chemisto, 2019). It is the proxy for the availability of labor and represents the total number of people over the age of 15 and above, employed, and unemployed that are available for work. Mobile cellular subscriptions per 100 people show subscriptions to mobile technology in a country. Mobile phone subscription is included as the indicator of information and communication technology (ICT) which is a more contemporary driver of economic growth (Steinmueller, 2001; Niebel, 2018; Adeleye and Eboagu, 2019). Lastly, inflation, which indicates economic fluctuations, is calculated from the consumer price index measures the annual percentages of the inflation rate. It is included to capture economic variations across countries in the sample (Adeleye and Eboagu, 2019).

\subsection{Empirical Model}

The analytical model is built on the common growth model expressed in implicit form as: $Y=f\left(X_{1}, \ldots, X_{n}\right)$

Where $\mathrm{Y}$ represents economic growth, and $\mathrm{X}$ is the vector of variables that influence economic growth. The explicit form of the model is stated as:

$y_{i t}=a_{i t}+\beta X_{i t}^{\prime}+\left(\eta_{i}+\epsilon_{i t}\right)$

Where $y$ is economic growth, $a$ is the constant term, $i$ is the spatial dimension of countries 1,2 , $\ldots, \mathrm{N} ; t$ denotes times; $1,2, \ldots, \mathrm{N}, X$ represents factors influencing economic growth; $\eta_{i}$ captures unobserved country-specific effects; $\epsilon_{i t}$ is the idiosyncratic error term. Equation [2] is estimated by static and dynamic techniques. In the static model, the approach is to capture both the variation across time or space. However, static models are subject to criticisms. Firstly, some explanatory variables might be endogenous due to correlation with the error term, and some country-specific effects might correlate with the explanatory variable as well. Secondly, economic growth is a dynamic process. Hence, a dynamic model might better capture relationships. Hence, to overcome measurement errors, endogeneity, omitted variables, and possible heteroskedasticity, the system generalized method of moments (System-GMM) proposed by Arellano and Bover (1995) and 
Blundell and Bond (1998) is applied. The Sys-GMM technique uses moment conditions to achieve model efficiency. Two common tests are used to specify the estimation and instrument validity the Hansen test of overidentifying restrictions and the test for second-order serial correlation of the error terms. In particular, the Sys-GMM is specified as:

$y_{i t}=\Phi y_{i t-1}+\beta x_{i t}+\partial_{t}+\epsilon_{i t}$

where $y_{i t-1}$ denotes lag of the dependent variable, $\partial_{t}$ controls for time dimensions and $\epsilon_{i t}$ is the composite error term, $i=1,2, \ldots, N, t=1,2, \ldots, T$ where $N$ and $T$ denote the number of countries and years, respectively.

\section{Results and Discussions}

\subsection{Correlation Analysis and Descriptive Statistics}

The pairwise correlation analysis in Table 1 reveals that economic growth exhibit positive and statistically significant associations with FDI, capital formation, and the labor force. The associations between economic growth, government expenditure, and mobile subscriptions are significant but negative. Also, among the regressors, there is no evidence of perfect linear associations; hence, the problem of multicollinearity is averted.

Table 1: Correlation Matrix

\begin{tabular}{llllllll}
\hline Variables & GDPgr & FDI & GE & GCF & LF & MOB & INF \\
\hline GDPgr & 1.000 & & & & & & \\
FDI & $0.136^{* *}$ & 1.000 & & & & & \\
GE & $-0.176^{* * *}$ & -0.0279 & 1.000 & & & & \\
GCF & $0.230^{* * *}$ & $0.150^{* *}$ & 0.0581 & 1.000 & & & \\
LF & $0.103^{*}$ & -0.0792 & $-0.220^{* * *}$ & $0.126^{* *}$ & 1.000 & & \\
MOB & $-0.116^{*}$ & -0.0242 & $0.120^{* *}$ & 0.0762 & 0.0247 & 1.000 & \\
INF & -0.0489 & -0.0000323 & $-0.178^{* * *}$ & -0.0581 & 0.0604 & $-0.162^{* * *}$ & 1.000 \\
\hline
\end{tabular}

Note: ${ }^{*} p<0.05,{ }^{* *} p<0.01,{ }^{* * *} p<0.001$ represent statistical significance at the $5 \%, 1 \%$ and $0.1 \%$.

Source: Authors' Computations

Table 2 presents the descriptive statistics for the full sample. The overall GDP growth is $4.65 \%$.

The growth rates for the two groups of low and lower middle income are $4.8 \%$ and $4.5 \%$, respectively. Accordingly, low-income countries have higher FDI and inflation rates, where lowmiddle income countries have higher rates of GE, GCF, LF, and mobile cellular subscriptions. 
Table 2: Descriptive Statistics

\begin{tabular}{lcccccc}
\hline \multirow{2}{*}{ Variables } & \multicolumn{2}{c}{ Full Sample } & \multicolumn{2}{c}{ Low Income } & \multicolumn{2}{c}{ Lower Middle Income } \\
\cline { 2 - 7 } & Mean & SD & Mean & SD & Mean & SD \\
\hline GDPgr & 4.657 & 4.292 & 4.8 & 4.88 & 4.568 & 3.885 \\
FDI & 4.906 & 9.613 & 6.288 & 13.03 & 4.042 & 6.518 \\
Govt. Exp. & 14.46 & 5.793 & 13.7 & 4.798 & 14.96 & 6.309 \\
Capital & 25.56 & 10.04 & 24.78 & 9.415 & 26.05 & 10.41 \\
Labour & 20.12 & 60.01 & 8.751 & 9.644 & 27.23 & 75.29 \\
Mobile & 77.62 & 31.82 & 58.18 & 26.95 & 89.77 & 28.45 \\
Inflation & 6.325 & 6.262 & 6.589 & 6.321 & 6.165 & 6.231 \\
\hline
\end{tabular}

Note: SD = Standard Deviation

Source: Authors' Computations

We present our results in three steps. First, we estimate the model by using the Pooled OLS (POLS). Secondly, we control for heterogeneity and estimate the random-effects model, and finally, we present the results of Sys-GMM models. Presenting model in three steps serves as a robustness check as well. The regression analyses on the full sample are performed using the Pooled OLS(POLS), random effect(RE), and Sys-GMM. Due to limited numbers of countries in each income group, the analyses on the income levels are performed only using the POLS model.

\subsection{Pooled OLS Results}

Table 3 shows the POLS results. Column [1] is the main results, and column [2] is the robustness checks with the inflation as the control variable. The results show that FDI and capital formation positively influence the level of economic growth. On average, ceteris paribus, a one percent increase in the FDI and capital formation, increases the economic growth by $3.8 \%$ and $9.9 \%$, respectively.

The impacts of the labor force on economic growth is positive and significant; however, it is magnitude is small as compared to the FDI and capital formation. On the other hand, government expenditure negatively impacts the level of growth. On average, ceteris paribus, a one percent increase in government expenditure, decreases economic growth by $10 \%$. Overall, the insignificant coefficient for low-income countries gives the indication that there are no significant differences between low and lower-middle-income countries. while the impact of mobile cellular subscriptions on economic growth is also statistically not significant 
The results in columns [2] are not significantly different from those of the main model in columns [1]. While controlling for inflation, the predictors retain the same coefficient signs and almost the same significance level. Inflation indicates a significant and negative correlation with economic growth, which implies that on average, an increase in the annual percentage of inflation decreases economic growth by $6 \%$, ceteris paribus. The income group dummy does not show any significant differences, an indication that both low and lower-middle-income countries are not significantly different in this study.

\begin{tabular}{lcc}
\multicolumn{3}{l}{ Table 3: Pooled OLS, Full Sample - Dependent Variable GDP Growth } \\
\hline Variables & Main Regression & Robustness Check \\
\hline FDI & $0.0386^{* *}$ & $0.0408^{* *}$ \\
& $(0.0160)$ & $(0.0177)$ \\
Government Expenditure & $-0.106^{* * *}$ & $-0.132^{* * *}$ \\
& $(0.0387)$ & $(0.0390)$ \\
Capital Formation & $0.0991^{* * *}$ & $0.0967^{* * *}$ \\
& $(0.0223)$ & $(0.0234)$ \\
Labor Force & $0.00375^{* *}$ & $0.00356^{* *}$ \\
& $(0.00161)$ & $(0.00154)$ \\
Mobile subscriptions & -0.00818 & $-0.0135^{*}$ \\
& $(0.00635)$ & $(0.00695)$ \\
Inflation & & $-0.0663^{*}$ \\
& & $(0.0339)$ \\
Low-income Countries & -0.105 & -0.187 \\
& $(0.388)$ & $(0.396)$ \\
Constant & $5.013^{* * *}$ & $6.088^{* * *}$ \\
& $(0.876)$ & $(1.067)$ \\
Observations & & \\
R-squared & 509 & 480 \\
Year Dummies & 0.124 & 0.136 \\
Robust standard errors in parentheses & YES & \\
$* * *$ p $<0.01, * * \mathrm{p}<0.05, * \mathrm{p}<0.1$ & &
\end{tabular}

For a better understanding of the puzzle of economic growth post-financial crises, the data is divided along with income levels. From Table 4, findings reveal that predictors of economic growth are not the same across countries with different income levels. For instance, FDI is a significant predictor of growth in low-income countries relative to lower-middle-income countries. On the contrary, government expenditure and mobile cellular subscriptions are not significant predictors in low-income countries relative to lower-middle-income countries. Interestingly, 
capital formation and labor force are the two common significant predictors across the two income level groups of incomes. Though the magnitude of each predictor on the countries with different income varies; however, they exhibit the same positive coefficients.

Table 4: Pooled OLS, Income Groups - Dependent Variable GDP Growth

\begin{tabular}{|c|c|c|c|c|}
\hline \multirow[b]{2}{*}{ Variables } & \multicolumn{2}{|c|}{ Main Regression } & \multicolumn{2}{|c|}{ Robustness } \\
\hline & $\begin{array}{l}\text { Low } \\
\text { income }\end{array}$ & $\begin{array}{l}\text { Lower middle } \\
\text { income }\end{array}$ & $\begin{array}{l}\text { Low } \\
\text { income }\end{array}$ & $\begin{array}{l}\text { Lower middle } \\
\text { income }\end{array}$ \\
\hline \multirow[t]{2}{*}{ FDI } & $0.0448 * *$ & 0.0472 & $0.0531 * * *$ & 0.0452 \\
\hline & $(0.0175)$ & $(0.0513)$ & $(0.0191)$ & $(0.0548)$ \\
\hline \multirow[t]{2}{*}{ Government Expenditure } & -0.0156 & $-0.120 * *$ & -0.0454 & $-0.147 * * *$ \\
\hline & $(0.0756)$ & $(0.0463)$ & $(0.0803)$ & $(0.0465)$ \\
\hline \multirow[t]{2}{*}{ Capital Formation } & $0.111 * *$ & $0.0716^{* * *}$ & $0.135 * *$ & $0.0680 * * *$ \\
\hline & $(0.0453)$ & $(0.0255)$ & $(0.0564)$ & $(0.0258)$ \\
\hline \multirow[t]{2}{*}{ Labor Force } & $0.0987 * * *$ & $0.00315^{*}$ & $0.0829 * * *$ & $0.00320 * *$ \\
\hline & $(0.0285)$ & $(0.00166)$ & $(0.0276)$ & $(0.00158)$ \\
\hline \multirow[t]{2}{*}{ Mobile Subscriptions } & 0.0183 & $-0.0158 * *$ & 0.0110 & $-0.0187 * *$ \\
\hline & $(0.0145)$ & $(0.00745)$ & $(0.0178)$ & $(0.00737)$ \\
\hline \multirow[t]{2}{*}{ Inflation } & & & -0.00112 & $-0.115^{* * *}$ \\
\hline & & & $(0.0529)$ & $(0.0397)$ \\
\hline \multirow[t]{2}{*}{ Constant } & $507.6 *$ & $433.1 *$ & 246.4 & $400.4^{*}$ \\
\hline & $(293.2)$ & $(226.3)$ & $(304.9)$ & $(235.0)$ \\
\hline Observations & 199 & 310 & 184 & 296 \\
\hline R-squared & 0.165 & 0.150 & 0.167 & 0.179 \\
\hline Year Dummies & Yes & Yes & Yes & Yes \\
\hline
\end{tabular}

We checked the robustness of our model at the income level by using inflation as a control variable. The result reported above in columns [3] and [4] of Table4, confirm the consistency of results.

\subsection{Random Effect Results}

Controlling for the panel heterogeneity, the augmented model is estimated using the random effects $(\mathrm{RE})^{2}$ technique. The results reported in Table 5, approximate almost those of POLS. The signs and significance levels are quite similar. FDI and capital formation depict a positive and

\footnotetext{
${ }^{2}$ The p-value for Hausman test is 0.0568 which supports the suitablity of randem effect models as compared to the fixed effects technique.
} 
significant influence on economic growth. Similarly, the labor force evidences a significant and positive impact but with minimal magnitude on economic growth. At the same view, mobile cellular subscriptions do not indicate any significant influence on the level of economic growth. Consistent with the results of POLS, government expenditure significantly decreases the level of growth.

\begin{tabular}{|c|c|c|}
\hline Variables & Main RE & Robustness Check \\
\hline FDI & $\begin{array}{c}0.0430 * * * \\
(0.0167)\end{array}$ & $\begin{array}{c}0.0460^{* *} \\
(0.0188)\end{array}$ \\
\hline Government Expenditure & $\begin{array}{l}-0.105 * * \\
(0.0412)\end{array}$ & $\begin{array}{c}-0.127 * * * \\
(0.0391)\end{array}$ \\
\hline Capital Formation & $\begin{array}{l}0.110 * * * \\
(0.0299)\end{array}$ & $\begin{array}{c}0.106 * * * \\
(0.0307)\end{array}$ \\
\hline Labor Force & $\begin{array}{l}0.00383 * * \\
(0.00175)\end{array}$ & $\begin{array}{l}0.00385 * * \\
(0.00170)\end{array}$ \\
\hline Mobile Subscriptions & $\begin{array}{l}-0.00782 \\
(0.00739)\end{array}$ & $\begin{array}{c}-0.0115 \\
(0.00817)\end{array}$ \\
\hline Inflation & & $\begin{array}{l}-0.0578 \\
(0.0402)\end{array}$ \\
\hline Constant & $\begin{array}{c}3.438 * * * \\
(1.079)\end{array}$ & $\begin{array}{c}4.594 * * * \\
(1.331)\end{array}$ \\
\hline Observations & 509 & 480 \\
\hline Year Dummies & YES & YES \\
\hline
\end{tabular}

While controlling for inflation, the results from the robustness check are quite similar to those of the main model.

\subsection{System GMM Results}

Table 6 details the outcomes from the system GMM procedure, where the first lag of GDP growth is used as the internal instrument and the independent variables as external instruments. Column [1] shows the main results, and in column [2], we control for inflation as a robustness check. The results from Sys-GMM align with those of POLS and RE models. Evidence supports that FDI plays a significant role in the growth of low and middle low-income countries and suggests that an increase in FDI enhances economic growth by $16 \%$, on average, ceteris paribus. Similarly, 
capital formation increases growth by $9 \%$. On the contrary, government expenditure reduces economic growth and shows that a unit increase in government expenditure decreases the growth level by $9 \%$ on average, ceteris paribus.

The labor force is a consistently positive and statistically significant predictor of growth. However, the magnitude of the impact is small. Like the results of the previous two models, the mobile cellular subscription does not indicate any significant impact on economic growth. The insignificance could be due to the lack of technological infrastructures in low-income countries, contrary to developed countries. Mobile technology facilitates business transactions. In recent years, several successful businesses are conducted using mobile phones and ICT networks. However, in low-income countries, due to the lack of technological infrastructure, the mobile phone is used only as a means of communication. This may indicate that low-income countries need to expand the backbone of technology infrastructure to boost the economy.

Table 6: Sys-GMM, Full Sample - Dependent Variable GDP Growth

\begin{tabular}{lcc}
\hline VARIABLES & Main Sys-GMM & Robustness Check \\
\hline GDP Growth $)_{t-1}$ & $0.161^{* *}$ & $0.163^{* *}$ \\
FDI & $(0.069)$ & $(0.075)$ \\
& $0.044^{* *}$ & $0.049^{*}$ \\
Government Expenditure & $(0.022)$ & $(0.024)$ \\
& $-0.098^{* *}$ & $-0.115^{* * *}$ \\
Capital Formation & $(0.037)$ & $(0.035)$ \\
& $0.090^{* * *}$ & $0.088^{* * *}$ \\
Labor Force & $(0.028)$ & $(0.030)$ \\
& $0.003^{* *}$ & $0.003^{* *}$ \\
Mobile Subscriptions & $(0.002)$ & $(0.002)$ \\
& -0.004 & -0.008 \\
Inflation & $(0.007)$ & $(0.008)$ \\
& & -0.037 \\
Low-income Countries & & $(0.039)$ \\
Constant & 0.024 & 0.011 \\
& $(0.459)$ & $(0.463)$ \\
Observations & $2.836^{* * *}$ & 0.000 \\
Year Dummies & $(1.004)$ & $(0.000)$ \\
AR(1) p-value & & \\
AR(2) p-value & 446 & 419 \\
Hansen test p-value & Yes & Yes \\
\hline
\end{tabular}

Note: Robust standard errors in parentheses; *** $\mathrm{p}<0.01, * * \mathrm{p}<0.05, * \mathrm{p}<0.1$

Source: Authors Computations 
For curiosity, the robustness of our model is checked at the income level. The results reported in column [2] of Table 6 validate our findings, indicating consistencies across all model specifications.

\section{Conclusion and Findings}

Economic determinants differ across the low and middle-lower-income countries. For instance, FDI is a significant predictor of growth in low-income countries but not in lower-middle-income countries, while the impact of government expenditure and mobile cellular subscriptions differ significantly across income groups. Interestingly, capital formation and labor force are the two common significant predictors across the two groups of incomes. Therefore, it might be difficult, and even invalid to generalize the determinants of growth across countries. Particularly, outcomes from post-financial crises in our study indicate that countries with the same or small income variation respond differently to various determinants of growth.

\section{References}

Abiad, A., Furceri, D. and Topalova, P. (2016) 'The macroeconomic effects of public investment: Evidence from advanced economies', Journal of Macroeconomics. Elsevier Ltd, 50, pp. 224-240. doi: 10.1016/j.jmacro.2016.07.005.

Adeleye, N. and Eboagu, C. (2019) 'Evaluation of ICT development and economic growth in Africa', NETNOMICS: Economic Research and Electronic Networking. Springer New York LLC, 20(1), pp. 31-53. doi: 10.1007/s11066-019-09131-6.

Adom, P. K., Opoku, E. E. O. and Yan, I. K. M. (2019) 'Energy demand-FDI nexus in Africa: Do FDIs induce dichotomous paths?', Energy Economics. Elsevier BV, 81, pp. 928-941. doi: 10.1016/j.eneco.2019.05.030.

Agosin, M. R. and Machado, R. (2005) 'Foreign investment in developing countries: Does it crowd in domestic investment?', Oxford Development Studies. TF , 33(2), pp. 149-162. doi: $10.1080 / 13600810500137749$.

Aizenman, J. et al. (2018) 'Flexibility of Adjustment to Shocks: Economic Growth and Volatility of Middle-Income Countries Before and After the Global Financial Crisis of 2008', Emerging Markets Finance and Trade. Routledge, 54(5), pp. 1112-1131. doi: 10.1080/1540496X.2017.1422430.

Arellano, M. and Bover, O. (1995) 'Another look at the instrumental variable estimation of error- 
components models', Journal of Econometrics. North-Holland, 68(1), pp. 29-51. doi: 10.1016/0304-4076(94)01642-D.

Aschauer, D. A. (1989) 'Is public expenditure productive?', Journal of Monetary Economics. North-Holland, 23(2), pp. 177-200. doi: 10.1016/0304-3932(89)90047-0.

Balcão Reis, A. (2001) 'On the welfare effects of foreign investment', Journal of International Economics. North-Holland, 54(2), pp. 411-427. doi: 10.1016/S0022-1996(00)00100-8.

Banerjee, A. V and Duflo, E. (2011) Poor economics: A radical rethinking of the way to fight global poverty. Public Affairs.

Barro, R. J. (1989) 'The Ricardian Approach to Budget Deficits', Journal of Economic Perspectives. American Economic Association, 3(2), pp. 37-54. doi: 10.1257/jep.3.2.37.

Barro, R. J. (1990) 'Government Spending in a Simple Model of Endogeneous Growth', Journal of Political Economy. University of Chicago Press, 98(5, Part 2), pp. S103-S125. doi: $10.1086 / 261726$.

Barro, R. J. and Sala-I-Martin, X. (1992) 'Public Finance in Models of Economic Growth', The Review of Economic Studies. Oxford University Press (OUP), 59(4), p. 645. doi: 10.2307/2297991.

Blanchard, O., Cerutti, E. and Summers, L. (2015) Inflation and Activity - Two Explorations and their Monetary Policy Implications. Cambridge, MA. doi: 10.3386/w21726.

Bloom, D., Canning, D. and Chan, K. (2006) Higher Education and Economic Development in Africa. Working Paper 102. Washington, D. C.

Blundell, R. and Bond, S. (1998) 'Initial conditions and moment restrictions in dynamic panel data models', Journal of Econometrics. Elsevier BV, 87(1), pp. 115-143. doi: 10.1016/S03044076(98)00009-8.

Borensztein, E., De Gregorio, J. and Lee, J. W. (1998) 'How does foreign direct investment affect economic growth?', Journal of International Economics. North-Holland, 45(1), pp. 115-135. doi: 10.1016/S0022-1996(97)00033-0.

Brecher, R. A. and Diaz Alejandro, C. F. (1977) 'Tariffs, foreign capital and immiserizing growth', Journal of International Economics. North-Holland, 7(4), pp. 317-322. doi: 10.1016/00221996(77)90048-4.

Carare, A. et al. (2018) 'Globalization and the New Normal', IMF Working Papers, 18(75), p. 1. doi: 10.5089/9781484350645.001.

Cerra, V. and Saxena, S. (2017) Booms, Crises, and Recoveries: A New Paradigm of the Business Cycle and its Policy Implications, IMF Working Papers. doi: 10.5089/9781484325759.001. 
Chami, R. et al. (2010) 'The Global Financial Crisis and Workers' Remittances to Africa: What's the Damage?', IMF Working Papers. International Monetary Fund (IMF), 10(24), p. 1. doi: 10.5089/9781451962413.001.

Chen, W., Mrkaic, M. and Nabar, M. (2019) The Global Economic Recovery 10 Years After the 2008 Financial Crisis, IMF Working Papers. doi: 10.5089/9781498305426.001.

Dedrick, J., Kraemer, K. and Shih, E. (2013) 'Information technology and productivity in developed and developing countries', Journal of Management Information Systems. Routledge, 30(1), pp. 97-122. doi: 10.2753/MIS0742-1222300103.

Dolphin, T. and Chappell, L. (2010) The Effect of the Global Financial Crisis on Emerging and Developing Economies. London: Institute for Public Policy Research (IPPR).

Dunne, J. P. and Masiyandima, N. (2017) 'Bilateral FDI from South Africa and Income Convergence in SADC', African Development Review. Blackwell Publishing Ltd, 29(3), pp. 403415. doi: 10.1111/1467-8268.12277.

Ghosh, S. and Gregoriou, A. (2008) 'The composition of government spending and growth: Is current or capital spending better?', Oxford Economic Papers. Oxford University Press, 60(3), pp. 484-516.

Grier, K. B. and Tullock, G. (1989) 'An empirical analysis of cross-national economic growth, 1951-1980', Journal of Monetary Economics. North-Holland, 24(2), pp. 259-276. doi: 10.1016/0304-3932(89)90006-8.

Griffith-Jones, S. and Ocampo, J. A. (2009) The financial crisis and its impact on developing countries. Brasilia: International Policy Centre for Inclusive Growth (IPC-IG). Available at: http://hdl.handle.net/10419/71832.

Gurtner, B. (2010) 'The financial and economic crisis and developing countries', International Development Policy| Revue internationale de politique de développement. Institut de hautes études internationales et du développement, 1(1), pp. 189-213.

Herzer, D. (2012) 'How Does Foreign Direct Investment Really Affect Developing Countries' Growth?', Review of International Economics. John Wiley \& Sons, Ltd, 20(2), pp. 396-414. doi: 10.1111/j.1467-9396.2012.01029.x.

Holmes, J. M. and Hutton, P. A. (1990) 'On the Casual Relationship between Government Expenditures and National Income', The Review of Economics and Statistics. JSTOR, 72(1), p. 87. doi: $10.2307 / 2109743$.

IMF (1988) 'The Growth of Government Expenditure: A Review of Quantitative Analysis', IMF Working Papers. International Monetary Fund (IMF), 88(17), p. i. doi: 10.5089/9781451922844.001. 
IMF (2010) World Economic Outlook April 2010 Rebalancing Growth, World Economic and Financial Surveys. Washington, D. C. Available at: https://www.imf.org/en/Publications/WEO/Issues/2016/12/31/World-Economic-Outlook-April2010-Rebalancing-Growth-23342 (Accessed: 19 May 2020).

Jacobs, C., Rivett, U. and Chemisto, M. (2019) 'Developing capacity through co-design: the case of two municipalities in rural South Africa', Information Technology for Development. Routledge, 25(2), pp. 204-226. doi: 10.1080/02681102.2018.1470488.

Jawaid, S. T. and Waheed, A. (2017) 'Contribution of International Trade in Human Development of Pakistan', Global Business Review. Sage Publications India Pvt. Ltd, 18(5), pp. 1155-1177. doi: 10.1177/0972150917710345.

Kandil, M. (2006) 'Variation in the effects of government spending shocks with methods of financing: Evidence from the US', International Review of Economics and Finance. JAI, 15(4), pp. 463-486. doi: 10.1016/j.iref.2004.09.001.

Keynes, J. M. (1936) The General Theory of Employment, Interest and Money. New York: Macmillan.

Kneller, R., Bleaney, M. F. and Gemmell, N. (1999) 'Fiscal policy and growth: Evidence from OECD countries', Journal of Public Economics. Elsevier, 74(2), pp. 171-190. doi: 10.1016/S0047-2727(99)00022-5.

Kumar, N. and Pradhan, J. P. (2005) 'Foreign Direct Investment, Externalities and Economic Growth in Developing Countries: Some Empirical Explorations', in Multinationals and Foreign Investment in Economic Development. Palgrave Macmillan UK, pp. 42-84. doi: 10.1057/9780230522954_3.

Landau, D. (1983) 'Government Expenditure and Economic Growth: A Cross-Country Study', Southern Economic Journal. JSTOR, 49(3), p. 783. doi: 10.2307/1058716.

Lin, S. A. Y. (1994) 'Government spending and economic growth', Applied Economics. Chapman \& Hall Ltd., 26(1), pp. 83-94. doi: 10.1080/00036849400000064.

Loening, J. L. (2005) Effects Of Primary, Secondary, And Tertiary Education On Economic Growth: Evidence From Guatemala. Working Paper 3610. Washington, D. C: The World Bank.

Loizides, J. and Vamvoukas, G. (2005) 'Government Expenditure and Economic Growth: Evidence from Trivariate Causality Testing', Journal of Applied Economics. Informa UK Limited, 8(1), pp. 125-152. doi: 10.1080/15140326.2005.12040621.

Mankiw, N. G., Romer, D. and Weil, D. N. (1992) 'A Contribution to the Empirics of Economic Growth', The Quarterly Journal of Economics. Oxford University Press (OUP), 107(2), pp. 407437. doi: $10.2307 / 2118477$. 
McCord, A. (2010) 'The impact of the global financial crisis on social protection in developing countries', International Social Security Review. John Wiley \& Sons, Ltd, 63(2), pp. 31-45. doi: 10.1111/j.1468-246X.2010.01360.x.

De Mello, L. R. (1997) 'Foreign direct investment in developing countries and growth: A selective survey', Journal of Development Studies. Frank Cass Publishers, 34(1), pp. 1-34. doi: $10.1080 / 00220389708422501$.

Naudé, W. (2009) Financial Crisis of 2008 and the Developing Countries, Un-Wider. Helsinki: WIDER Discussion Paper.

Naudé, W. (2010) 'The Global Economic Crisis and Developing Countries: Effects, Responses and Options for Sustainable Recovery', Poverty \& Public Policy. Wiley-Blackwell, 2(2), pp. 395419. doi: 10.2202/1944-2858.1050.

Niebel, T. (2018) 'ICT and economic growth - Comparing developing, emerging and developed countries', World Development. Elsevier Ltd, 104, pp. 197-211. doi: 10.1016/j.worlddev.2017.11.024.

Nurkse, R. (1971) 'The Theory of Development and the Idea of Balanced Growth', in Developing the Underdeveloped Countries. Palgrave Macmillan UK, pp. 115-128. doi: 10.1007/978-1-34915452-4_9.

Nyasha, S. and Odhiambo, N. M. (2019) 'Government Size and Economic Growth: A Review of International Literature', SAGE Open. SAGE Publications Inc., 9(3), p. 215824401987720. doi: $10.1177 / 2158244019877200$.

Olofsdotter, K. (1998) 'Foreign direct investment, country capabilities and economic growth', Weltwirtschaftliches Archiv. Springer, 134(3), pp. 534-547. doi: 10.1007/bf02707929.

Papaioannou, S. K. and Dimelis, S. P. (2007) 'Information technology as a factor of economic development: Evidence from developed and developing countries', Economics of Innovation and New Technology. Routledge, 16(3), pp. 179-194. doi: 10.1080/10438590600661889.

Pegkas, P. and Tsamadias, C. (2014) 'Does higher education affect economic growth? The case of Greece', International Economic Journal. Routledge, 28(3), pp. 425-444. doi: 10.1080/10168737.2014.894551.

Pegkas, P. and Tsamadias, C. (2016) 'How important are foreign and domestic investments, exports and human capital for Greece's economic growth?', Economic Issues, 21(Part 1), pp. 2345.

Qiang, Y. (2013) 'How does OFDI affect trade development in developing countries?', Journal of Chinese Economic and Foreign Trade Studies. Emerald Group Publishing Ltd., 6(2), pp. 85-90. doi: 10.1108/JCEFTS-05-2013-0020. 
Ram, R. (1989) 'Government Size and Economic Growth: A New Framework and Some Evidence from Cross-Section and Time-Series Data', The American Economic Review. American Economic Association, 76, pp. 191-203. doi: 10.2307/1804136.

Ratha, D., Mohapatra, S. and Silwal, A. (2010) Outlook for Remittance Flows 2010-11: Remittance Flows to Developing Countries Remained Resilient in 2009, expected to recover during 2010-11. World Bank, Washington, DC.

Reinhart, C. M. and Rogoff, K. S. (2014) Recovery from financial crises: Evidence from 100 episodes', American Economic Review. American Economic Association, 104(5), pp. 50-55. doi: 10.1257/aer.104.5.50.

Romer, P. (1993) 'Idea gaps and object gaps in economic development', Journal of monetary economics. North-Holland, 32(3), pp. 543-573.

Romer, P. M. (1986) 'Increasing Returns and Long-Run Growth', Journal of Political Economy. University of Chicago Press, 94(5), pp. 1002-1037. doi: 10.1086/261420.

Romer, P. M. (1990) 'Endogenous Technological Change', Journal of Political Economy. University of Chicago Press, 98(5, Part 2), pp. S71-S102. doi: 10.1086/261725.

Sen, K. (2011) “"A Hard Rain's a-Gonna Fall”: The Global Financial Crisis and Developing Countries', New Political Economy. Routledge, 16(3), pp. 399-413. doi: 10.1080/13563467.2011.540323.

Shen, W., Yang, S. C. S. and Zanna, L. F. (2018) 'Government spending effects in low-income countries', Journal of Development Economics. Elsevier BV, 133, pp. 201-219. doi: 10.1016/j.jdeveco.2018.02.005.

Sianesi, B. and Van Reenen, J. (2003) 'The returns to education: Macroeconomics', Journal of Economic Surveys. Blackwell Publishing Ltd, 17(2), pp. 157-200. doi: 10.1111/1467-6419.00192.

Solow, R. M. (1956) 'A Contribution to the Theory of Economic Growth', The Quarterly Journal of Economics. Oxford University Press (OUP), 70(1), p. 65. doi: 10.2307/1884513.

Steinmueller, W. E. (2001) 'ICTs and the Possibilities for Leapfrogging by Developing Countries', International Labour Review, $140 . \quad$ Available at: https://heinonline.org/HOL/Page?handle=hein.journals/intlr140\&id=219\&div=\&collection= (Accessed: 30 August 2020).

Sylwester, K. (2005) 'Foreign direct investment, growth and income inequality in less developed countries', International Review of Applied Economics. Taylor and Francis Ltd, 19(3), pp. 289300. doi: 10.1080/02692170500119748.

Traum, N. and Yang, S. C. S. (2015) 'When does government debt crowd out investment?', Journal of Applied Econometrics. John Wiley and Sons Ltd, 30(1), pp. 24-45. doi: 
10.1002/jae.2356.

World Bank (2010) Global Economic Prospects 2010: Crisis, Finance, and Growth, Global Economic Prospects. Washington, D. C. Available at: https://openknowledge.worldbank.org/handle/10986/2415 (Accessed: 20 May 2020).

Zagler, M. and Dürnecker, G. (2003) 'Fiscal policy and economic growth', Journal of Economic Surveys. Blackwell Publishing Ltd, 17(3), pp. 397-418. doi: 10.1111/1467-6419.00199. 


\section{List of Countries}

Table 1A: List of Countries

\begin{tabular}{|c|c|c|c|c|}
\hline No & Country Name & Code & Region & Income group \\
\hline 1 & Afghanistan & $\mathrm{AFG}$ & South Asia & Low income \\
\hline 2 & Angola & $\mathrm{AGO}$ & Sub-Saharan Africa & Lower middle income \\
\hline 3 & Bangladesh & BGD & South Asia & Lower middle income \\
\hline 4 & Benin & BEN & Sub-Saharan Africa & Low income \\
\hline 5 & Bhutan & BTN & South Asia & Lower middle income \\
\hline 6 & Bolivia & $\mathrm{BOL}$ & Latin America \& Caribbean & Lower middle income \\
\hline 7 & Burkina Faso & BFA & Sub-Saharan Africa & Low income \\
\hline 8 & Burundi & BDI & Sub-Saharan Africa & Low income \\
\hline 9 & Cabo Verde & CPV & Sub-Saharan Africa & Lower middle income \\
\hline 10 & Cambodia & KHM & East Asia \& Pacific & Lower middle income \\
\hline 11 & Cameroon & $\mathrm{CMR}$ & Sub-Saharan Africa & Lower middle income \\
\hline 12 & Central African Republic & CAF & Sub-Saharan Africa & Low income \\
\hline 13 & Chad & TCD & Sub-Saharan Africa & Low income \\
\hline 14 & Comoros & $\mathrm{COM}$ & Sub-Saharan Africa & Lower middle income \\
\hline 15 & Congo, Dem. Rep. & COD & Sub-Saharan Africa & Low income \\
\hline 16 & Congo, Rep. & $\mathrm{COG}$ & Sub-Saharan Africa & Lower middle income \\
\hline 17 & Egypt, Arab Rep. & EGY & Middle East \& North Africa & Lower middle income \\
\hline 18 & El Salvador & SLV & Latin America \& Caribbean & Lower middle income \\
\hline 19 & Eswatini & SWZ & Sub-Saharan Africa & Lower middle income \\
\hline 20 & Ethiopia & ETH & Sub-Saharan Africa & Low income \\
\hline 21 & Gambia, The & GMB & Sub-Saharan Africa & Low income \\
\hline 22 & Ghana & GHA & Sub-Saharan Africa & Lower middle income \\
\hline 23 & Guinea & GIN & Sub-Saharan Africa & Low income \\
\hline 24 & Guinea-Bissau & GNB & Sub-Saharan Africa & Low income \\
\hline 25 & Haiti & HTI & Latin America \& Caribbean & Low income \\
\hline 26 & Honduras & HND & Latin America \& Caribbean & Lower middle income \\
\hline 27 & India & IND & South Asia & Lower middle income \\
\hline 28 & Indonesia & $\mathrm{IDN}$ & East Asia \& Pacific & Lower middle income \\
\hline 29 & Kenya & KEN & Sub-Saharan Africa & Lower middle income \\
\hline 30 & Kyrgyz Republic & KGZ & Europe \& Central Asia & Lower middle income \\
\hline 31 & Lao PDR & $\mathrm{LAO}$ & East Asia \& Pacific & Lower middle income \\
\hline 32 & Lesotho & LSO & Sub-Saharan Africa & Lower middle income \\
\hline 33 & Liberia & LBR & Sub-Saharan Africa & Low income \\
\hline 34 & Madagascar & MDG & Sub-Saharan Africa & Low income \\
\hline 35 & Malawi & MWI & Sub-Saharan Africa & Low income \\
\hline 36 & Mali & MLI & Sub-Saharan Africa & Low income \\
\hline 37 & Mauritania & MRT & Sub-Saharan Africa & Lower middle income \\
\hline
\end{tabular}




\begin{tabular}{|c|l|l|l|l|}
38 & Moldova & MDA & Europe \& Central Asia & Lower middle income \\
\hline 39 & Mongolia & MNG & East Asia \& Pacific & Lower middle income \\
\hline 40 & Morocco & MAR & Middle East \& North Africa & Lower middle income \\
\hline 41 & Mozambique & MOZ & Sub-Saharan Africa & Low income \\
\hline 43 & Nepal & MMR & East Asia \& Pacific & Lower middle income \\
\hline 44 & Nicaragua & NPL & South Asia & Low income \\
\hline 45 & Niger & NER & Sub-Saharan Africa & Low income \\
\hline 46 & Nigeria & NGA & Sub-Saharan Africa & Lower middle income \\
\hline 47 & Pakistan & PAK & South Asia & Lower middle income \\
\hline 48 & Philippines & PHL & East Asia \& Pacific & Lower middle income \\
\hline 49 & Rwanda & RWA & Sub-Saharan Africa & Low income \\
\hline 50 & Senegal & SEN & Sub-Saharan Africa & Lower middle income \\
\hline 51 & Sierra Leone & SLE & Sub-Saharan Africa & Low income \\
\hline 52 & Sudan & SDN & Sub-Saharan Africa & Lower middle income \\
\hline 53 & Tajikistan & TJK & Europe \& Central Asia & Low income \\
\hline 54 & Tanzania & TZA & Sub-Saharan Africa & Low income \\
\hline 55 & Timor-Leste & TLS & East Asia \& Pacific & Lower middle income \\
\hline 56 & Togo & TGO & Sub-Saharan Africa & Low income \\
\hline 57 & Tunisia & TUN & Middle East \& North Africa & Lower middle income \\
\hline 58 & Uganda & UGA & Sub-Saharan Africa & Low income \\
\hline 59 & Ukraine & UKR & Europe \& Central Asia & Lower middle income \\
\hline 60 & Uzbekistan & UZB & Europe \& Central Asia & Lower middle income \\
\hline 61 & Vanuatu & VUT & East Asia \& Pacific & Lower middle income \\
\hline 62 & Vietnam & VNM & East Asia \& Pacific & Lower middle income \\
\hline 63 & West Bank and Gaza & PSE & Middle East \& North Africa & Lower middle income \\
\hline 64 & Zambia & ZMB & Sub-Saharan Africa & Lower middle income \\
\hline 65 & Zimbabwe & ZWE & Sub-Saharan Africa & Lower middle income \\
\hline & & &
\end{tabular}

